\title{
Stories Notebook about the Fundamental Concepts in Family Medicine: Context and Contextualization, The Fable Of the Seagull, The Dove, The Crow And The Albatross
}

\author{
Jose Luis Turabian*
}

Health Center Santa Maria de Benquerencia Toledo, Spain

"Corresponding author: Jose Luis Turabian, Health Center Santa Maria de Benquerencia Toledo, Spain, Tel: 34925154508; E-mail: jturabianf@hotmail.com

Received date: January 10, 2017; Accepted date: January 16, 2017; Published date: January 23, 2017

Copyright: ( 2017 Turabian JL. This is an open-access article distributed under the terms of the Creative Commons Attribution License, which permits unrestricted use, distribution, and reproduction in any medium, provided the original author and source are credited.

\section{Introduction}

In this section of Stories Notebook about the Fundamental Concepts in Family Medicine, you will learn the fundamental concepts of General Medicine/Family Medicine through stories or fables.

Conceptual systematization in the specialty of Family Medicine/ General Medicine has not matched with practice. However, it is not until that the conceptual heritage of Family Medicine, is ordered, systematized and fully clarified when it can begin the real practical work.

Therefore, it is necessary to achieve more meaningful representations of the fundamental concepts of Family Medicine, and facilitate the transfer of these to clinical practice. But, these concepts can be difficult to understand and explain, even for experienced physicians in the specialty $[1,2]$. Thus, we propose the following concepts of Family Medicine/General Medicine, which we think are the main:

1. Comprehensiveness and integrality

2. Continuity

3. Context and contextualization

4. Uncertainty

5. Complexity

6. Community

7. Patient-centered interview

8. Biopsicosocial model

9. Actors and resources/strengths of the patients

10. Medicalization and technology

11. Family

12. Symptoms

13. Diagnosis and treatment

14. Concept of health and disease; and

15. Variability

Evidence-Based Medicine, clinical trials and quantitative studies are necessary, indispensable for medical science, yes, but why not the stories, the tales and the cases? So, we will be presented these concepts by fables [3-7].

The fable is an adult education method that can serve to intuitively understand abstract concepts by linking them to specific situations, for facilitating their assimilation. Animals, plants, minerals and other things will be "patients" seen in consultation by the family doctor.

They will be fictional stories presented as real. They will be beings or objects that are given the opportunity to think, feel and speak. In the fable it can be distinguished two parts: one is the story itself; and the other moral. Each story seeks to make emerge, of clear form, the moral, the end of the fable, as sobering consequence of what happened in the episode [1]. The moral will be a fundamental concept of Family Medicine/General Medicine.

\section{Short Communication}

Once upon a time, a Seagull, 20 years old, a bird with a white plumage, beak orange, ash-colored back, legs, and webbed fingers joined by a membrane, which lived with her husband in a colony of flat ground on the beach, near the marshes of the rivers, where it had a simple, shallow nest and covered of grass. Mrs. Seagull had been treated by several high-profile psychiatrists. She took a benzodiazepine because of anxiety about her partner's problems. But the effect of the treatment was actually to weaken the relationship with her husband, in a psychological sense. Because of that the relationship with her husband was at the root of her problems so, the specific treatment was counteracting with regard to a contextual or situational treatment [8-14].

Once upon a time, a dove, with predominantly white feathers, $25 \mathrm{~cm}$ long and $400 \mathrm{gm}$ of weight, which lived in a nest made with twigs and straw, in the hollows of a wall of a building. She fed on vegetables, grains, seeds, and food scraps she was looking for in the trash, Mrs. Dove was diabetic, and the endocrinologist had told her to follow a stricter diet. This restriction interfered with her relationship with friends, which involved eating together on social occasions. Mrs. Dove reduced social contacts and thus became more isolated in her nest.

Once upon a time there was a Crow, a large, obese bird, of $60 \mathrm{~cm}$ long and a weigh of $1.7 \mathrm{~kg}$, with black plumage and blue and purple reflections. Mr. Crow had been diagnosed of gonarthrosis, using NMR and RX, and since he had pain in his legs when moving, the traumatologist recommended that he limit his physical activities. Thus, he limited his flights and lay down and dozed near the forest, and only lifted up his head lazily to observe what was happening around him. But this big rest was a further risk factor for their gonarthrosis to developing further, and the rest induced him to feed on excess cereals, berries, fruits, small invertebrates, amphibians, reptiles, small mammals and birds, gaining even more weight and worsening their gonarthrosis (Figure 1) $[9,10]$. 
Citation: Turabian JL (2017) Stories Notebook about the Fundamental Concepts in Family Medicine: Context and Contextualization, The Fable Of the Seagull, The Dove, The Crow And The Albatross. 2329-9126+non 5: 286. doi:10.4172/2329-9126.1000286

Page 2 of 2

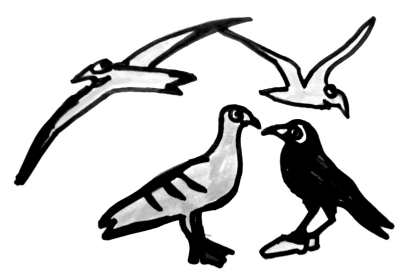

Figure 1: The fable of the seagull, the dove, the crow and the albatross.

Once upon a time an albatross, this was an old and very large bird, with a plumage of a dark coloration on the upper part of the wings, while the lower part was white. Mrs. Albatross had been labeled as osteoporotic, after conducting Bone Densitometry, and that caused her fear of falls, and resulting in a reduction in mobility, failing to travel the usual great distances with their usual gliding flight, which led to a greater acceleration of bone loss, and an impoverished of his diet [11-14]. The family doctor was somewhat surprised:

"In these patients are as if a biomedical decision acted as a mistake that gave rise to new pernicious coincidences" thought the doctor.

Interventions based only on biomedical data, taking regardless of context, even if they are of the latest technology, can have negative consequences [15-17]. To work in Family Medicine without an orientation towards the context is to deprive the patient of reality, to isolate him or her from daily life as if existed in a material vacuum, to strip her or him of their multiple determinations, to strip it of the continuity of history, of her or him biography.

\section{References}

1. Skrabanek P (1998) The death of humane medicine. Humane medicine and the rise of coercive healthism. The Social Affairs Unit. Bury St Edmunds, Suffolk: St Edmundsbury Press Ltd, UK.
2. Turabian JL (2003) Una medicina a escala humana. JANO; LXV: 1489.

3. Carpintero E, Abril RT (2007) La medicalización de la vida cotidiana.

4. Miralda PG, Ferreira-González I (2006) Hacia la perversión de la medicina basada en le videncia? 126: 497-9.

5. Palomo Cobos L (2004) Virtud y virtuosismo de las nuevas tecnologías en Atención Primaria Semergen30: 114-119.

6. Weiss RJ (1980) The biopsychosocial model and primary care. Psychosomatic medicine 42: 123-130.

7. Le Baron S (2004) Can the future of medicine be saved from the success of science? Acad Med 79: 661-665.

8. May C (2006) Mobilising modern facts: health technology assessment and the politics of evidence. Sociology of Health \& Illness 28: 513.

9. Lauer MS (2009) Elements of Danger. The Case of Medical Imaging. Eng J Med 361: 841-843.

10. Turabian JL, Franco PB (2001) Actividades Comunitarias en medicina de familia y atención primaria. Madrid: Díaz de Santos.

11. Illich I (1978) Medical nemesis. The expropriation of health. Pantheon books, New York, USA.

12. Turabian JL (2005) Inteligencia contextual JANO LXIX 1571: 10.

13. Turabian JL, Franco BP (2007) Big Mysteries. Can You see the loch ness monster? The biopsychosocial model and community activities. Aten Primaria 39: 261-264.

14. Turabian JL, Franco PB (2008) Atención médica individual con orientación comunitaria-Atención contextualizada: la figura es el fondo. Revista Clínica Electrónica en Atención Primaria

15. Turabian JL. Evidence does not make decisions, people "in contexts" do. BMJ 2002; 324:1350.

16. Trotter G (2002) Physician and Philosopher: The Philosophical Foundation of Medicine: Essays by Dr. Edmund Pellegrino. JAMA 288: 3171-3173. 